\title{
Artelogie
}

Recherche sur les arts, le patrimoine et la littérature de l'Amérique latine

$5 \mid 2013$

Femmes créatrices en Amérique latine : le défi de synthétiser sans singulariser

\section{Editorial: Women Artists in Latin America: the challenge of synthetizing without singularizing}

Ana Paula Cavalcanti Simioni, Deborah Dorotinsky and Maira de Luca

\section{OpenEdition}

\section{Journals}

Electronic version

URL: https://journals.openedition.org/artelogie/5096

DOI: 10.4000/artelogie.5096

ISSN: $2115-6395$

Publisher

Association ESCAL

\section{Electronic reference}

Ana Paula Cavalcanti Simioni, Deborah Dorotinsky and Maira de Luca, "Editorial: Women Artists in Latin America: the challenge of synthetizing without singularizing", Artelogie [Online], 5 | 2013, Online since 16 October 2013, connection on 20 December 2021. URL: http://journals.openedition.org/ artelogie/5096 ; DOI: https://doi.org/10.4000/artelogie.5096

This text was automatically generated on 20 December 2021.

Association ESCAL 


\title{
Editorial: Women Artists in Latin America: the challenge of synthetizing without singularizing
}

\author{
Ana Paula Cavalcanti Simioni, Deborah Dorotinsky and Maira de Luca
}

1 Between 1974 and 1979 within the seventies feminist movement, American artist Judy Chicago conceived her emblematic work, Dinner Party (1979), a symbolic banquet which gathered 1030 women, from different historical periods. While 39 of them were evoked at the table, the rest were named on the ceramic tiles arranged in the grand installation, in a manner which celebrated-while at the same time promoted-a feminine tradition until then not recognized by dominant historiography. In that great community, some ethnocentric limits of Anglo-Saxon feminism became evident, as was then noted by Estelle Chacon; none of the New World heroines figured amongst those invited to share the table, on the contrary, "Hispanas" as well as "Black women" appeared, barely named on the tiles disposed on the floor, thus signaling the symbolic space they occupy in the narrative put forth by the emergent feminism in the United States and England ${ }^{1}$.

2 Reactions to this work, which became one of "egalitarian" feminism's icons, did not take long. Since 1977, Griselda Pollock had denounced in her text "What's wrong with images of Women?" what she termed "vaginal imagery", which tended to reduce multiple feminine identities to a single stable signifier, derived from their biological bodies. Against a univocal image, Pollock-who perhaps is today the most influential name in feminist art historiography-proposed a deconstruction of feminine images, a critique to stabilizing discourses, in sum, to all types of reductions, even those operated by feminism itself. Roughly since de decade of 1980 , it is possible to assert that "egalitarian" feminism gave way to that of difference. We must also consider the contribution of Gayatri Chakavorty Spivak to postcolonial literary criticism through her article "Imperialism and Sexual Difference" (1986) where she points out the need to move from a merely "oppositional" feminism towards a "critical" one, capable of continuous examination of the ways in which feminism imbricates itself in institutions 
and ideologies. In that respect, authors like Chéla Sandoval (1995), played a significant role in the problematization of Anglo-Saxon feminism of the 1960/70s, which presupposed a single feminist subject, stable and hegemonic that did not translate into a way of addressing the expectations, desires, or realities lived by the "others of feminism". Thus, "feminine" issues were pierced by questions of class and ethnicity.

We could say that in the artistic field the debate fostered analysis that swerved towards paying closer attention to images of women disseminated by artworks, the media, the press and cinema, as fundamental spaces for the promotion and crystallization of normative social discourses. They began to be considered as "gender technologies" (De Laurentis, 1987). Since then, more than promoting positive images of femininity, feminist art historiography began to look closer into those representations (Arruda, 2013).

4 However, when we think of the field of gender studies and art in Latin America, we find ourselves with a complex situation because the story of feminist thinking does not occur as we narrated above; often, "egalitarian" and "difference" feminist texts reaches the readers' hands within the same temporal frame. Besides, research nourishes itself from paradigms developed by Anglo-Saxon theories, some of which have as one of their stepping-stones Linda Nochlin's famous article "Why have there been no great women artists?". Here the author argues that the scant recognition received by women artists through art history was a result of social and institutional factors, particularly the unequal access to the conditions of artistic training and formation, thus establishing the parameters upon which a feminist art historiography would be founded. Nonetheless, it is relevant to acknowledge that the realities upon which the term "Latin America" is based are very different from those that propitiated the emergence of those feminist theories. These theories need to be revisited, revised, adapted and even elaborated anew when they are contrasted with the different contexts of Latin American women artists ${ }^{2}$. It is also important to recall that the reception of Nochlin's ideas, for example, did not occur simultaneously or equably in the countries that make up Latin America. While in Mexico since the beginning of the 1970s these texts circulated and impacted academic discussions, arriving thus to art institutions, as Andrea Giunta's article in this number well shows, in other cases, like that of Brazil, where feminine and feminist artistic production is considerable, even today Nochlin's famous text has not been translated into Portuguese. Between these extremes, we can quote the case of Argentina whose capital, Buenos Aires, was the stage of various feminist experiments during the seventies, as María Laura Rosa analyzes well in her article "El despertar de la conciencia. Impacto de las teorías feministas sobre las artistas de Buenos Aires durante las décadas del ' 70 y ' 80 ”, on dissenting productions made from the margins of the artistic system. As Luana Saturnino Tvardovskas asserts in "Tramas feministas na arte contemporânea brasileira e argentina", the fact that feminist artistic productions in Brazil and Argentina were organized in a different manner to those in Anglo-Saxon countries, in a less institutionalized fashion, a less identity-bound way, with out large collective exhibits or a more forthright revision of the artistic cannons, does not weaken the feminine poetics encompassed in many of the art works produced there. These considerations are relevant so we can comprehend the difficulty (or impossibility?) in constructing unified theoretical and methodological scaffoldings to understand such diverse artistic productions and historical situations. 
5 The present number of Artelogie proposes to contribute to the debate on gender and art by covering a very ample and varied panorama of research on and about women artists in Latin America, since the XIX century up to contemporary productions. We will not attempt to search for a monolithic theory, or a complete and exhaustive mapping of the production of women artists in all Latin America. Above all, we present the reader with a selection of texts that have analytic density and verticality, but that cover experiences, productions and poetics developed in different countries thorough a rather large time span. We attempted to give priority to those artistic expresions that have been less written about in the region (like visual arts, music and design), a limitation which left out literary practices, which already have a well established tradition and a vast number of publications in our region.

6 The first block of essays analyze how gender questions traverse the processes of identity discourses as nationalism and identity formation processes arose during the XIX century in different countries in Latin America, in the midst of political autonomy struggles. These discourses materialize in-and through-artistic forms. Together with foundation novels (Doris Sommer, 2010), paintings constituted real and effective visual discourses with a pedagogical character. In them, though tense and complex articulations, certain dichotomies-viewed then as irreconcilable-like civilization/ barbarism, dominators (white)/ dominated (indigenous and/or black), active/passive, man/woman, were transcended, appeased, or domesticated. The feminine body occupies a central political, visual and symbolic place in that conflicting civilizing process; the dilemma of mestizaje. This centrality is shown in Josefina de la Maza's article on the paintings of Monvoisin, particularly in Elisa Bravo Jaramillo de Bañados, mujer del cacique, as in Tatiana Lotierzo and Lilia Katri M. Schwarcz demonstrate for the young Brazilian Republic in their approach to the well known painting by Modesto Broccos, Redenção de Cã.

7 Through different artistic practices-like music, engraving or sculpture-another group of articles deal with the entrance of women artists into what we have called "peripheral modernities" (Sarlo, 1999). The insertion of women in the artistic fields can be attested though the XIX century in diverse Latin American countries, particularly those that underwent a process of institutionalization of artistic routines based on overseas models that culminated in the founding of Art Academies, like those of Mexico, Brasil, Argentina and Chile. In general, the French post revolutionary Academy model was followed, one that did not consider the inclusion of women as disciples, but accepted them in the annual Salons (Simioni, 2008). This meant that women did not have full access to artistic training, like their male colleagues did have. However, certain abilities were not only tolerated but also fostered, as long as they were constitutive of the ideals of bourgeois femininity disseminated throughout these nations.

Georgina Gluzman's explains in her article "El trabajo recompensado: mujeres, artes y movimientos femeninos en la Buenos Aires de entre-siglos" how an ambiguous situation was taking shape in Argentina at the end of the XIX century, filled with tensions that came, on the one hand, from normative social expectations on longed for femininity and, on the other, from the concrete conditions for professionalization 
which women enjoyed. In"Del caballete al telar. La Academia Nacional de Bellas Artes, las escuelas profesionales y los debates en torno de la formación artística femenina en la Argentina de la primera mitad del siglo XX", Julia Ariza deploys that outlook by focusing on the conditions for artistic training accessible to women in Argentina during the height of modernization. Gloria Cortez deals with like issues but making a case for Chilean women artists in "Estéticas da resistencia: las artistas chilenas y la vanguardia femenina (1900-1936)", where she discusses the obstacles faced by women in order to receive artistic education, as well as addressing the aesthetic modalities of "transgression" they were able to effect against patriarchal discourse then in force. In "Género y cultura visual. Adrienne Macaire-Bacle en La historia del arte argentino", Lia Munilla, Sandra Szir y Georgina Gluzmann reconstruct and reinterpret the career of pioneer engraver Macaire-Bacle in Buenos Aires at the onset of the XIX century. Through an original research based on primary sources, the authors discuss this artist's neglected production in a format and support regarded as "minor" and essentially masculine. Dalila Vasconcelos also intertwines in her analysis a discussion of gender and artistic media in "Du salon à la scène: l'ascension des femmes et du piano au brésil du vingtième siècle", where she interprets the transformations in the Brazilian music scene during the Belle époque (c.1889-1930), when three notable pianist emerged (Antonieta Rudge, Magda Tagliaferro e Guiomar Novaes). The author demonstrates how gradually the position of piano soloist became a viable feminine prerogative, and points out how the trajectories and production of these women musicians gave shape to a way of overcoming gender asymmetries in such a manner that a new position was made available for them in the Brazilian music scene, a socially recognized and legitimate position.

9 We use the term "peripheral modernities" because in the Spanish and Portuguese speaking regions of the American continent, artists involved in modernist avant-gardes adopted and adapted some of the forms derived from so called "ethnic" and/or "popular" repertoires, thus bearing a hybrid modernism, or "anthropophagic", as it has also been termed ${ }^{3}$. In this respect, some of the articles in this issue of Artelogie are very telling of the ways women gained access to fields dominated until then by men: architecture and industrial design between the years 1930 to 1950 in Mexico and Brazil. In "Lina Bo Bardi et l'architecture brésilienne de l'aprés guerre", Zeuler R. M. de Lima displays the development of Lina Bo Bardi's career and oeuvre towards the end of World War II. Bo Bardi, an Italian architect living in Sao Paulo, designed important works in Brazilian modernism, like the emblematic MASP building (Sao Paolo's Art Museum). Though little recognized internationally, the notoriety of her trajectory and works has grown over the last few years ${ }^{4}$. On her part, Ana Elena Mallet recuperates the path followed by industrial designer Clara Porset. Of Cuban origin but established in Mexico, Mallet shows us how Porset's strategic bonds with well recognized architects of her time allowed her to promote and advance her furniture and interior design products, ones that recuperated and interpreted Mexican popular and indigenous forms. We should add that Lina Bo Bardi also made a significant theoretical contribution for the appraisal of Brazilian artisanal tradition ${ }^{5}$. Michele Greet also deals with the problem of the articulation between the international momentum of modernism and local/national/popular inclinations as experienced by Latin American artists. She proposes a comparative analysis of 4 Latin American women artists showing in Paris during the 1920s: Brazilian Tarsila do Amaral and Anita Malfatti, Mexican Lola Velásques Cueto and Cuban Amélia Pelaez. Greet shows how each of them established 
different strategies in order to make themselves visible in the Parisian scene, making decisions that involved the topics to be represented, but also the materiality of the works themselves. She makes evident the extent to which these choices of materiality and subject matter implied negotiating different gendered implications. As the articles published in this issue allow us to unfold, gender aspects discriminate not only authors and modalities, but also impact the materiality of artistic practices, and the levels of legitimacy upon which they're classified and the artistic fields into which they are inscribed.

There are a significant number of articles that approach the work of contemporary women artists revealing the variety of topics that concern them; the body, sexuality, women's history and colonial practices, gender violence and maternity ${ }^{6}$. For the Mexican case, which stands out as an important center for the production and thought on Latin American feminist artistic practices during the 1970s, we have the articles "Cosas de mujeres? Feminst networks of collaboration in 1970's Mexico", by Gabriela Aceves, and "Feminist Disruption in Mexican Art, 1975-1987", by Andrea Giunta. Giunta's article proposes a reading of feminist interventions by artists like Pola Weiss, Mónica Mayer, Magali Lara and journalist and feminist activist Ana Victoria Jiménez, who made a feminist scenario possible within Mexican artistic circles: they introduced transgressive and insubordinate corporealities, ones that were often made invisible even by feminist art historiography in the country. The article contributes thus, to a reading that liberates the potential of such unconventional artworks, intervening in a corpus of images that have been immobilized by rigid art historical classifications.

11 Women artists' political and aesthetically transgressive potential is also dealt with in a group of articles that revisit artistic production during the authoritarian contexts that affected different Latin American countries from the 1960s to the 1980s. Art works as spaces of political resistance and as oppositional discourses to domestic femininity's "naturalness" are interpreted by Giulia Lamoni in "(Domestic) Spaces of Resistance: Three Artworks by Anna Maria Maiolino, Letícia Parente and Anna Bella Geiger", centered in the Brazilian case but are also dealt with for the Colombian one by Gina McDaniel Tarver in her article on Colombian artist Feliza Bursztyn. The same problematic reappears in María Luisa Rosa's article, where she analyzes the works of María Luisa Bemberg and Monique Altschul, thus displaying the degree of feminist political and artistic conscience present in some porteño artistic circuits during the dictatorship. Luana Saturnino's article delves on the production of two artists, one Brazilian, the other Argentinian, who were active during the period of transition to democracy in both countries 1980 and 1990), whom nonetheless inherit a feminine poetics that actually bursts and develops in the previous decades marked by fierce authoritarianism. It is relevant to note that these feminine poetics consist of "radical maneuvers" that seek to question upheld ideological discourses through the works' materiality. Recovering mediums like embroidery, sewing, decoration, textiles and watercolor, which had traditionally been considered as "crafts" or "domestic", and thus were regarded as aesthetically inferior, these artists operate dislocating the traditional sense of these mediums, or giving them new meanings; they reveal the way through which social inequalities and asymmetries are inscribed in our art-worlds. Subverting, dislocating and deconstructing of femininity become ways of transforming modalities, mediums, practices and hierarchies within the artistic field. 

the contribution of women artists to political critique. As Nelly Richard asserts, the condition of doubly dominated allow women artists to travel from a condition of "marginality as exteriority to power, to margins as ways of questioning the symbolism of power" (RICHARD, 2011: p. 40) However, we most point out that though the oeuvres might be blunt, this does not imply that the artists identify themselves as "feminists". Many of them refused, and even today continue to decline to be catalogued as feminist. With this we must acknowledge and underline the difference recognized from within artistic and political practices between for a whish for general "militancy" and a feminist militancy tout court. Many of the artists analyzed have produced works that signal to a feminist poetics, without their makers' interest or attraction to any kind of militancy outside the artistic field itself. transformation in the mediums used by present day artists: photography, video, installation and performance, or even mixed media, govern production. For example, as Raquel Torres-Arzola shows in her approach to Puerto Rican artist Elsa María Melendez, the manipulation of silkscreen or engraving on embroidery and their montage in boxes, serve as elements that promote an adequate syntax to the social sceen where feminine bodies circulate. We can also notice the use of appropriation and resignification of traditional imagery, as in the remarkable case of Brazilian artist Adriana Verejão, interpreted here by Alice Heeren who displays the interweaving of race and gender and makes social fragmentation evident through her approach. A like methodology is also visible through-out Jamie Ratliff's text and interpretation of Daniela Rosell's photographic series "Ricas y Famosas", where the artist questions domestic space, a topic also dealt with in several other articles. Ratliff proposes a way of reading the space of the "home", one that has traditionally defined what it meant to be a woman, as the keystone of the Mexican nation. In the text, the "home" appears as a space of representation where the power and authority of the State invade the lives of citizens and allows for the reproduction of power by means of the perpetuation of traditional gendered roles.

y, we would like to comment that this number of Artelogie also includes a Reprise section where we tried to offer the reader two classic, and not readily available texts, on art and gender in Latin America. Laura Malosetti's article "El rapto de las cautivas blancas: un aspect erótico de la barbarie en la plastica Rioplatense del siglo XIX", is one of the pioneer examples of the interpretation, by means of a gender perspective, of the myth of white conquest in literature and art. With originality and creativity, Malosetti entwines in this article-already a classic in her written production and a methodological forerunner-both literary and visual sources on the topic of the abduction of white women by Indians (dealing with abduction and captivity scenes) thus pointing out the crossings between gender, race and social class. The second text, Angélica Velázquez' 'Juliana and Josefa Sanromán: The Representation of Bourgeois Domesticity in Mexico, 1850-1860", appearing in English for the first time and revised by the author, presents us with the painterly production of the Sanromán sisters, both students of the director of painting in the San Carlos Academy. Velázquez displays the way in which nineteenth century Mexican señoritas could access painting instruction and the topics they favored in their works, according to the social class they belonged to. Alongside these two articles, we also offer our readers an interview with 
Argentinian Art Historian Laura Malosetti Costa, whose reflection on the relations between art, gender and power, present in her frequent publications, conferences, papers, etc...can be taken as incentive for thought and research in other socioeconomic contexts.

The texts gathered here, regarded from within the geopolitical contexts of their production, allow us to asses reactions to the canonical constructions of gender, the "wars" against these cannons, as Gloria Cortez states in her text, considering the unavoidable and ever more relevant critical and rhetorical productivity of counter-discourses (and counter-histories) generated against gender, race and class stereotypes though-out Latin America.

\section{BIBLIOGRAPHY}

ARRUDA, Lina Alves (2013). Estratégias desconstrutivas: a crítica feminista da representação". Dissertação de Mestrado em Artes Visuais, Escola de Comunicações e Artes, São Paulo, 2013. BROUDE, Norma Broudeand and GARRARD, Marry (1982). Feminist Art History: Questioning the Litany.New York, Harper \& Row Publishers.

BARTRA, Eli. (2005) Mujeres en el Arte Popular. De Promesas, traiciones, monstrous y celebridades. México, Universidad Autónoma Metropolitana.

CANCLINI, Nestor G. (1990). Culturashíbridas. Estrategias para entrar y salir de lamodernidad, México, Grijalbo.

DE DIEGO, Estrella (2008). “Durante El feminismo de la igualdad: Historiografía, teoría y prácticas artísticas". Madrid, Exitbook: feminismo y arte de género, n.9.

DE LAURETIS, Teresa. (1987). Technologies of Gender.Essays on Theory, Film and Fiction.Bloominton, Indiana University Press.

DOROTINSKY, Deborah (2008). "Mirar desde los márgenes o los márgenes de la mirada. Fotografía por dos mujeres indígenas de Chiapas”, Debate Feminista, Año 19,Vol. 38, octubre 2008.

EDER, Rita. (1982). “Las mujeres artistas en México”, en Anales del Instituto de Investigaciones Estéticas, México, IIE-UNAM, Vol XIII, núm. 50, tomo 2, pp.251-259.

FERRAZ, Isa Grinspum (org.)(1994). Tempos de grossura. O design no impasse. Série Pontos sobre o Brasil. São Paulo, Instituto Lina Bo e P.M. Bardi.

GIASSON, Patrice (ed.) (2010). Brincando fronteras. Creaciones locales mexicanas y globalización. México, CONACULTA.

GIUNTA, Andrea (2011). "Estrategias de lamodernidad en América Latina”. In: Escribir las Imágenes.Buenos Aires, SigloVeintiuno.

HOLANDA, Heloisa e HERKENHOFF, Paulo (2006).Manobras radicais. Rio de Janeiro, Centro Cultural Banco do Brasil. 
HUYSSEN, Andrea (2010). “Geografias Del Modernismo”, In: Modernismo Después de la Posmodernidad.Buenos Aires, Gedisa Editorial.

JONES, Amelia (2011). “ Les politique ssexuelles de The Dinner Party. Un contexte très critique (1996-2005), IN: DUMONT, Fabienne (ed). La Rébellion du Deuxième Sexe. L'histoire de l'art au crible des théories féministes anglo-américaines (1970-2000). Les Presses du Reél.

MAYAYO, Patricia. (2008). '¿Por qué no ha habido (grandes) artistas feministas en España?. Apuntes sobre una historia en busca de autor' en Xabier Arakistain; Lourdes Méndez:Producción artística y teoríadel arte: nuevos debates I, Vitoria, Centro Cultural MontehermosoKulturunea.

NOCHLIN, Linda (1991).Why there be no great women artists?". In:_Art and Sexual Politics. New York, Macmillan Publishing Co.

POLLOCK, Griselda.(1999) “Tracing figures of presence, naming ciphers of abscence. Feminism, Imperialism, and Post modernity in the Work of SutapaBiswas". In BLOOM, Lisa. (1999) With other eyes. Looking at Race and Gender in Visual Culture.Minneapolis / Londres, University of Minnesota Press.

POLLOCK, Griselda (1977). “What's wrong with Images of Women?”, Screen Education, 1977, no24, 25-33.

RUBINO, Silvana (2009). Lina por escrito: textos escolhidos de Lina Bo Bardi, 1943-1991. São Paulo, Cosac\&Naify.

SANDOVAL, Chéla Sandova (1995).l "Feminist forms of Agency and Oppositional Consciousness: U.S. Third World Femenist Criticism" en KEGAN GARDINER, Judith. (1995) Provoking Agents.Genderand Agency in Theoryand Practice. Urbana and Chicago, Universityof Illinois Press.

SARLO, Beatriz (1999). Una Modernidad Periférica: Buenos Aires 1920-1930. Buenos Aires, Nueva Vision.

SCHWARTZ, Jorge (2003). Brasil: 1920-1950. Da Antropofagia à Brasília.São Paulo: Museu de Arte Brasileira/ Cosac \&Naify.

SIMIONI, Ana Paula C. (2008). Profissão artista: pintoras e escultoras acadêmicas brasileiras (1884-1922). São Paulo, EDUSP/FAPESP.

SPIVAK, Gayatri Chakravorty. (1986) “Imperialismand Sexual Difference”.oxford Literary Review 8, pp.517-529.

SOMMER, Doris. (2010)“Um romance irresistible: las ficciones fundacionales de América Latina”. In: BHABHA, Homi (compilador). Nación y Narración. Buenos Aires, SigloVeintiuno Editores.

\section{NOTES}

1. To see this work view link: https://www.brooklynmuseum.org/exhibitions/dinner_party/

2. Interestingly, some Spanish authors established a very similar critique in that feminist art historiography in Spain ought to rethink the hegemony of Anglo-Saxon models used to explain artistic production in their country. See DE DIEGO (2008); MAYAYO (2008). For further reading see Luana Saturnino's and María Laura Rosa's articles in this issue.

3. Bibliography for this matter is incredibly ample thus we recommend but a few examples here: Canclini (2009), Sarlo (1999). Schwartz (2003), Huyssen (2010), Giunta (2011).

4. Rubino, Silvana (2009).

5. In this respect we recommend "Tempo de Grossura", a text first published in 1980, and organized by Isa Grispum Ferraz (1994). 
6. The editors are well aware that the topic of women artist of indigenous origin (First Nations) was not considered as it should have been. We recommend to look at BARTRA (2005), DOROTINSKY (2008) and GIASON editor (2010).

7. HOLANDA, H. e HERKENHOFF (2006).

\section{AUTHORS}

ANA PAULA CAVALCANTI SIMIONI

IEB/USP

DEBORAH DOROTINSKY

UNAM

MAIRA DE LUCA

CRAL-EHESS 